Central Washington University

ScholarWorks@CWU

$10-2005$

\title{
Penrose conference report: Kinematics and geodynamics of intraplate dextral shear in eastern California and western Nevada
}

\author{
Jeffrey Lee \\ Central Washington University, jeff@geology.cwu.edu \\ Daniel Stockli \\ University of Kansas \\ Christopher Henry \\ University of Nevada, Reno \\ Timothy Dixon \\ University of Miami
}

Follow this and additional works at: https://digitalcommons.cwu.edu/geological_sciences

Part of the Geophysics and Seismology Commons, and the Tectonics and Structure Commons

\section{Recommended Citation}

Lee, J., Stockli, D., Henry, C., \& Dixon, T. (October, 2005). Penrose conference report: Kinematics and geodynamics of intraplate dextral shear in eastern California and western Nevada. GSA Today, 15(10), 28-29.

This Article is brought to you for free and open access by the College of the Sciences at ScholarWorks@CWU. It has been accepted for inclusion in Geological Sciences Faculty Scholarship by an authorized administrator of ScholarWorks@CWU. For more information, please contact scholarworks@cwu.edu. 


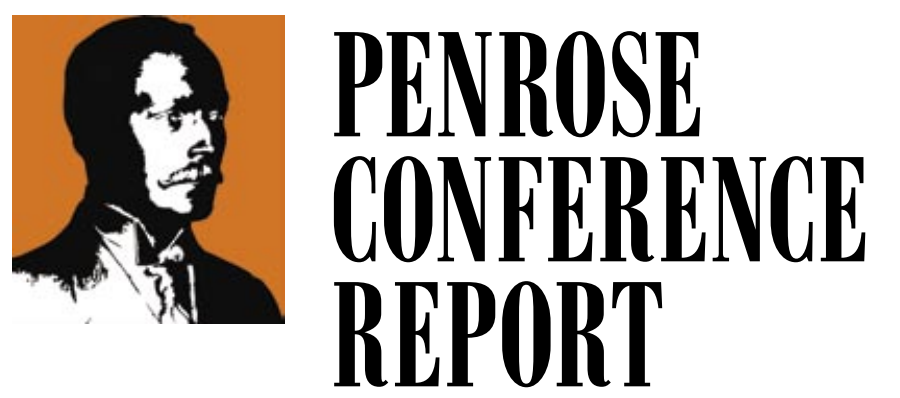

Kinematics and Geodynamics of Intraplate Dextral Shear in Eastern California and Western Nevada

21-26 April 2005

\section{Mammoth Mountain Inn, Mammoth Lakes, California}

\section{Conveners:}

Jeffrey Lee, Department of Geological Sciences, Central Washington University, Ellensburg, Washington, USA

Daniel Stockli, Geology Department, University of Kansas, Lawrence, Kansas, USA

Christopher Henry, Nevada Bureau of Mines and Ceology, University of Nevada, Reno, Nevada, USA

Timothy Dixon, Marine Geology \& Geophysics Division, Rosenstiel School of Marine and Atmospheric Science, University of Miami, Miami, Florida, USA

This conference provided a forum to discuss the range of geological and geophysical datasets from the eastern California shear zone (ECSZ) and Walker Lane belt (WLB) that bear on how intraplate deformation is accommodated and how to integrate the data into a comprehensive, spatially and kinematically coherent view of intraplate deformation through time. The session goals were to discuss what we know about deformation in this region at a range of spatial and temporal scales, how to integrate the longer temporal view provided by geologic data with the instantaneous present-day view provided by geodetic and geophysical data, what geomorphic tools can be used to link geodetic and geologic fault slip rate data, whether magmatism and faulting are linked, the geodynamic hypotheses proposed for the evolution of the region, and the uncertainties associated with interpretations. The conference brought together 68 researchers, including 17 graduate students and four international participants, from academia, the U.S. Geological Survey, industry, and the U.S. Nuclear Regulatory Commission.

The conference opened with evening overviews on the plate tectonic setting of western North America by Tanya Atwater and the geologic setting of the United States Cordillera by Brian Wernicke. Atwater summarized how plate motions are determined via rigid plate circuit recon- structions and noted that these reconstructions show a change in Pacific-North America relative plate motion ca. $8 \mathrm{Ma}$. She illustrated these global plate motions, as well as Pacific-North America plate motions, via a series of computer animations. The Pacific-North America plate motion animations highlighted the kinematically coordinated links among plate motions and continental tectonics. Wernicke's presentation summarized a new tectonic reconstruction for southwestern North America that shows that the Sierra Nevada-Great Valley block has moved $\sim 235 \mathrm{~km} \mathrm{~N} 78^{\circ} \mathrm{W}$ with respect to the Colorado Plateau since ca. $16 \mathrm{Ma}$. He also highlighted transient deformation recorded in geodetic data collected across the Basin and Range and suggested that a "megadetachment" at the base of the crust is one possible explanation for these transient deformations.

The first full day of the conference was a field trip to view evidence for active dextral, normal, and sinistral fault slip, as well as contraction and the kinematics of fault slip transfer in the ECSZ/WLB. The field trip, led by Jeff Lee and Danny Stockli, visited sites along the White Mountains fault zone, Queen Valley fault system, and the Coaldale fault. The evening was dedicated to posters on the geology of the eastern California shear zone. Poster topics ranged from the transition from extension to transtension in Panamint Valley by Joe Andrew to testing geodesy from fault slip rates in the Mojave Desert by Mike Oskin.

Sessions during the second full day of the conference concentrated on the geology and geodesy of the ECSZ and WLB. Rick Bennett discussed geodetic deformation rates across the ECSZ. Doug Walker focused on the mismatch between geologically determined rates for individual faults versus geodetic rates and orientation, style, and geometry of deformation in close proximity of the Garlock fault. John Oldow combined data from the GPS velocity field, seismicity, and tectonic boundaries to argue for constrictional strain during transtension to produce displacement partitioning in the southern WLB. Jim Faulds discussed the kinematics of active faulting in the northern WLB and proposed that the WLB was propagating northward as part of the development of an incipient transform plate boundary. The evening was dedicated to posters on regional and Walker Lane belt geology. Poster topics ranged from Basin and Range normal faulting in southeastern Oregon by Kaleb Scarberry to comparing the evolution of the ECSZ/ WLB to the proto-gulf of California by Paul Umhoefer.

The third day of sessions focused on two topics: a morning session on the links among climate, tectonics, and geomorphology and an afternoon session on the interplay between magmatism and tectonics. Kelin Whipple and Eric Kirby emphasized that tectonic geomorphology provides information on intermediate time scale rates and thereby the link between geodetic and geologic rates, noting that tectonic processes can be inferred from topographic observations. Whipple and Kirby discussed the use of drainage knickpoints and channel gradients to elucidate relative rates of rock uplift histories. Each provided an example of the use of this geomorphic tool from a different tectonic setting - the San Gabriel Mountains and the eastern side of the Inyo Mountains. Subsequent discussion focused on 


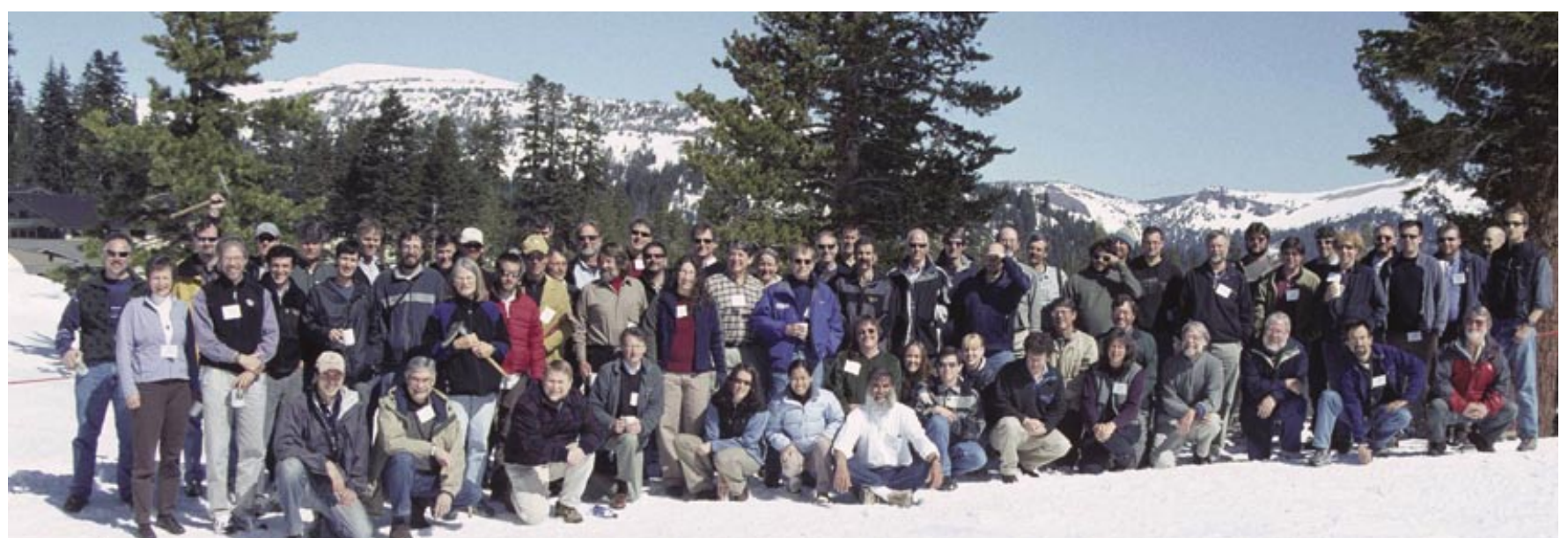

these topics and geochronologic techniques applicable to Quaternary time scales. Allen Glazner began the afternoon session with the interplay between magmatism and tectonics by showing an animation of the spatial and temporal distribution of magmatism in the western United States using 26,000 data points in the NAVDAT (navdat.geongrid.org) data set. Obvious magmatic patterns included a Pliocene mafic magmatic event in the Sierra Nevada and eastern California; the southward dying-out of silicic volcanism in Nevada; $12-0$ Ma westward migration of magmatism from western Nevada, through Death Valley to Owens Valley; and magmatism circumnavigating the southern edge of the Colorado Plateau. Chris Henry and his colleagues argued that complex interactions between basement structures, including Mesozoic faults and batholiths and the Cenozoic caldera belt, and magmatic heating by the ancestral Cascade arc focused dextral shear in the western Great Basin. For example, the southwestern limit of a NW-striking, 100- to 200-km-wide caldera belt through central Nevada parallels the northeastern edge of the WLB, including the right step at the Mina deflection. This simple observation led to much discussion about its tectonic significance. That evening, we reconvened for a poster session on geodynamics, geophysics, reconstructions, and volcanism. Topics ranged from an animation showing a strain-compatible kinematic model of deformation in the western Cordillera during the past 36 m.y. by Nadine McQuarrie to mass flux in the continental crust by Dennis Harry to the geodynamic driving forces for the uplift of the Sierra Nevada by Craig Jones.

The last morning session of the conference centered on the geodynamic evolution of the ECSZ/WLB. Kevin Furlong discussed the relationship between geological and geophysical observations. In particular, he raised some important questions, including can geology/geodesy discrepancies provide us with important physical information on the crust and lithosphere?- what role does rheology play in localization of strain?-are elastic layer over viscoelastic halfspace models an appropriate model for ECSZ? Subsequent discussions centered on whether the upper crust is dragging the mantle or visa versa, and what is the best approach to use geologic and geophysical observations to produce a physically comprehensive model of driving forces. Gene Humphreys followed with a geodynamic talk that encompassed nearly the entire western United States and discussed the relative roles of grav- itational potential energy, boundary forces, and basal forces to localization and development of deformation. In the afternoon, participants rode the gondola to the top of Mammoth Mountain where Wes Hildreth provided an impromptu geologic tour of the greater Mammoth Mountain, Long Valley caldera, and Inyo Craters region. The conference ended with a discussion, lead by Tim Dixon, on the topic "Where do we go from here?" Unresolved issues, many remaining from the framework questions proffered by the conveners, include discrepancies between geologic and geodetic rates, the timing of initiation and character of intraplate deformation, the influence of magmatism on tectonics, and whether the ECSZ/WLB will evolve to become the sole boundary between the Pacific and North American plates.

Registration and logistics at the conference venue went very smoothly. Thanks to the Geological Society of America's Penrose Fund and the National Science Foundation for partially supporting the conference. The conference was a great success because keynote speakers provided stimulating presentations, moderators and recorders admirably kept the discussions going smoothly, and the attendees willingly shared their research and interpretations and contributed thoughtprovoking questions, comments, and discussions.

\begin{tabular}{|c|c|c|}
\hline Participants & Kurt Frankel & Nadine McQuarrie \\
\hline Ernie Anderson & Anke Friedrich & Christopher Menges \\
\hline Thomas Anderson & Kevin Furlong & Tye Numelin \\
\hline Joseph Andrew & & John Oldow \\
\hline Tanya Atwater & $\begin{array}{l}\text { Allen Glazner } \\
\text { Evan Goldstein }\end{array}$ & Michael Uskin \\
\hline Steve Bacon & $\begin{array}{l}\text { Evan Goldstern } \\
\text { Bill Hammond }\end{array}$ & Lewis Owen \\
\hline Rick Bennett & Dennis Harry & $\begin{array}{l}\text { Micnael Petronis } \\
\text { Silvio Pezzopane }\end{array}$ \\
\hline Byron Berger & Chris Henry & Marith Reheis \\
\hline $\begin{array}{l}\text { Ross Black } \\
\text { John Casteel }\end{array}$ & Wes Hildreth & Phillip Resor \\
\hline $\begin{array}{l}\text { Jonn casteel } \\
\text { Darrel Cowan }\end{array}$ & Dave Hill & Kaleb Scarberry \\
\hline Nancye Dawers & Gwyneth Hughes & Jeffrey Schroeder \\
\hline Craig DePolo & Gene Humphreys & Timothy Sheehan \\
\hline John Dembosky & Angela Jayko & John Stamatakos \\
\hline Tim Dixon & Craig Jones & Daniel Stockli \\
\hline James Dolan & Philip Justus & Daniel Sturmer \\
\hline Peter Drakos & Eric Kirby & Tatia Taylor \\
\hline Andreas Eckert & Corne Kreemer & Christopher Tinche \\
\hline James Faulds & Peter LaFemina & Paul Umhoefer \\
\hline Luigi Ferranti & Kimberly Le & Doug Walker \\
\hline David Ferrill & Richard Lease & Brian Wernicke \\
\hline ert Finkel & Jeff Lee & Kelin Whipple \\
\hline id Fountain & Rocco Malservisi & Caroline Whitehill \\
\hline
\end{tabular}

